\title{
Peter E. Rosenbaum: Volpe's understanding evolution
}

\author{
McGraw-Hill, New York, 2010, 282 pp with 160 black and white figures and tables, \\ Price \$67.19US, [ISBN 978-0-07-338323-1]
}

\section{H. S. Richardson}

Received: 13 May 2010 / Accepted: 20 May 2010 / Published online: 5 June 2010

(C) Springer Science+Business Media B.V. 2010

This is the seventh edition of a popular college text which is widely used for introductory level courses on evolution. This edition is comprised of eighteen chapters which cover everything from origin of life and molecular evolution to the history of life, adaptive radiation and speciation. The text is readable and at a level easily understood by beginning college students and so the book is likely to be recommended by many teachers. I was therefore disappointed to find symbiosis only dealt with on three pages of the book as part of a discussion or organelles and their evolution. Even that section is dated and could have been written soon after the publication of Lynn Margulis's book 'Origin of Eukaryotic Cells' 40 years ago! It very disheartening that a book published in 2010 could ignore the very large body of available research information which discusses the role of symbiosis in evolution and speciation as well as books such as that by Seckbach (2002) which underline the import role of symbiosis in every world ecosystem. An inclusion of even a small part of this information would have made this book on evolution, not only much better, but much more interesting for the students.

\section{References}

Seckbach J (2002) Symbiosis; mechanisms and model systems. Kluwer Academic, Dordrecht

D. H. S. Richardson $(\triangle)$

Environmental Studies, Saint Mary's University,

923 Robie Street,

Halifax, NS B3H 3C3, Canada

e-mail: david.richardson@smu.ca 